\title{
PERBAIKAN KUALITAS PADA PRODUK GENTENG DENGAN METODE SIX SIGMA
}

\author{
Shanty Kusuma Dewi*), Diyah Maslahatul Ummah \\ Jurusan Teknik Industri, Fakultas Teknik, Universitas Muhammadiyah Malang, \\ Jl. Raya Tlogomas 246, Malang, Jawa Timur 65144 Telp 0341551253/Fax 0341460435
}

(Received: October 15, 2018/ Accepted: July 24, 2019)

\begin{abstract}
Abstrak
Berkembangnya industri kecil dan menengah menimbulkan persaingan dalam industri. Hal ini membuat setiap usaha harus memperhatikan kebutuhan pelanggan. Kualitas merupakan salah satu faktor pemenuhan kebutuhan pelanggan dan merupakan jaminan yang harus diberikan oleh perusahaan kepada pelanggan. Industri yang menghasilkan kualitas produk yang baik akan mengurangi kerugian karena kegagalan produk. Produk yang sesuai spesifikasi dan seragam dapat dihasilkan dengan cara memperkecil variasi proses. Tujuan dari penelitian ini adalah mengimplementasikan konsep Six Sigma pada suatu industri yang memproduksi genteng. Six Sigma merupakan metode mengidentifikasi penyebab kecacatan pada produk maupun proses dengan memperbaiki permasalahan dan meningkatkan kualitas melalui siklus DMAIC (Define, Measure, Analysis, Improve, Control). Dari hasil penelitian didapatkan penurunan DPMO dari 29311 menjadi 8974,35 dan terjadi peningkatan nilai sigma level dari 3,35 menjadi 3,99 sigma.
\end{abstract}

Kata kunci: kualitas; Six Sigma; DMAIC; metode Taguchi

\begin{abstract}
[Quality Improvement On Tile Products With Six Sigma Method] The development of small and medium industries has led to competition in the industry. Competitions make every business must pay attention to customer needs. Quality is one of the factors fulfilling customer needs and is a guarantee that must be given by the company to customers. Industries that produce good quality products will reduce losses due to product failure. Products that meet specifications and uniforms can be produced by minimizing process variations. The purpose of this study is to implement the concept of Six Sigma in an industry that produces tile. Six Sigma is a method of identifying causes of defects in products and processes by fixing problems and improving quality through the DMAIC cycle (Define, Measure, Analysis, Improve, Control). From the results of the study, there was a decrease in DPMO from 29311 to 8974.35 and an increase in the sigma level from 3.35 to 3.99 sigma.
\end{abstract}

Keywords: quality; Six Sigma; DMAIC; Taguchi method

\section{Pendahuluan}

Dunia perindustrian yang semakin maju dan meningkat, menimbulkan persaingan antar perusahaan yang cukup ketat bagi perusahaan kecil maupun besar. Hal ini menuntut perusahaan memberikan yang terbaik bagi konsumen. Kualitas atau mutu suatu produk menjadi salah satu faktor penting yang berpengaruh untuk menjadi faktor keputusan yang diinginkan oleh konsumen. Tujuan utama produk adalah untuk memenuhi kebutuhan pelanggan. Konsumen sering menentukan tingkat presisi tertentu dalam kebutuhan akan produk. Kebutuhan khusus seperti itu kemudian

*Penulis Korespondensi.

E-mail: shanty@umm.ac.id menjadi sasaran kualitas bagi perusahaan penghasil. Sasaran lain untuk produk yang juga penting adalah keandalan dan daya tahan produk. Kegagalan produk akan dapat berdampak serius pada profitabilitas perusahaan melalui biaya langsung dan biaya tidak langsung (Juran \& Godfrey, 1999).

Pengendalian kualitas secara terus menerus menjadi salah satu cara untuk mengurangi kegagalan dalam proses produksi sehingga dapat menekan jumlah produk rusak dan juga digunakan untuk melihat adanya kesalahan dalam proses produksi. Secara umum, konsep dasar mengenai kualitas berupa kesesuaian dan karakteristik produk yang diinginkan konsumen. Menurut perbedaharaan ISO 8402 dan dari Standar Nasional Indonesia (SNI 19-8402-1991) kualitas merupakan keseluruhan ciri dan karakteristik 
produk atau jasa yang kemampuannya dapat memuaskan kebutuhan, baik yang dinyatakan secara tegas maupun tersamar (Ariani, 2014).

Salah satu cara untuk menghasilkan produk yang berkualitas adalah dengan mengurangi variasi dari proses. Six Sigma merupaka metode untuk meminimalisasi variasi dan mengurangi cacat yang terjadi pada proses produksi dengan cara melakukan improvement (H. Fransiscus, 2014). Metode pemecahan masalah kualitas dapat diatasi dengan Six Sigma karena pada umumnya Six Sigma dianggap sebagai alat statistik dalam hal perbaikan masalah baik itu produk maupun proses. Lebih lanjut, Six Sigma juga didefinisikan sebagai seperangkat alat yang diangkat dalam memanajemen mutu yang membangun kerangka kerja yang sesuai dengan standar untuk proses perbaikan (Gijo \& Scaria, 2014). Penelitian tentang aplikasi Six Sigma sudah dilakukan oleh (Dewi, 2012) dan (Fithri, 2019) tentang meminimasi cacat dengan metode Six Sigma pada perusahaan tekstil dan didapatkan hasil penurunan nilai DPMO dan terjadi peningkatkan level sigma. Penelitian dari (Ghiffari dkk, 2013), (Gijo \& Scaria, 2010), (Wibisono \& Suteja, 2013), (Handayani, P, \& Wibowo, 2012), (Caesaron \& Simatupang, 2015) telah mengaplikasikan metode Six Sigma dalam beberapa proses produksi untuk mengurangi kecacatan dan meningkatkan kualitas produk. Penelitian ini bertujuan untuk mengaplikasikan metode Six Sigma dengan memasukkan metode Taguchi pada tahap improve pada IKM yang memproduksi genteng. Penelitian (Shanmugaraja dkk, 2011) dalam penelitiannya telah mengimplementasikan Six Sigma dan Taguchi dalam upaya meningkatkan kualitas produk aluminium die casting dan dari metode tersebut didapatkan hasil penurunan level kecacatan.

\section{Metode Penelitian}

Pada penelitian ini yang menjadi obyek penelitian adalah produk genteng mantili yang merupakan produk genteng favorit dan sering dipesan oleh pelanggan. Data yang dibutuhkan adalah data atribut meliputi cacat pada genteng dan data penyebab kecacatan genteng. Data tersebut dapat diperoleh dengan cara melakukan pengamatan langsung dan brainstorming dengan pihak perusahaan. Berikut adalah penjelasan tahapan penelitian yang dilakukan berdasarkan siklus DMAIC.

\subsection{Fase Define}

Tahap ini berkaitan dengan identifikasi masalah proses atau produk yang mengalami kesalahan atau kegagalan sehingga perlu dilakukan perbaikan (supriyadi dkk, 2017). Pada fase ini dilakukan dengan mengidentifikasi permasalahan, proses penggambaran Operation Procces Chart (OPC) dan mengidentifikasi CTQ.

\subsection{Fase Measure}

Fase measure merupakan tahap mengumpulkan data yang meliputi data kinerja saat ini, data kecacatan, data kesalahan yang sering terjadi saat proses produksi. Hal-hal yang dilakukan pada fase ini adalah menghitung nilai DPMO dan nilai level sigma.

\subsection{Fase Analyze}

Pada fase analyze yaitu mencari dan menemukan pokok permasalahan dengan target adanya peluang perbaikan dengan cara mengidentifikasi akar penyebab atau sumber kegagalan produk. Hal yang dapat dilakukan dengan menggunakan diagram fishbone (diagram sebab-akibat). Dalam pelaksanaan fase ini dilakukan dengan pengumpulan data-data dari fase sebelumnya utnuk mengetahui penyebab kecacatan pada setiap CTQ. Penyebab kecaatan pada setiap CTQ dijadikan factor yang akan dianalisis pada tahap improve.

\subsection{Fase Improve}

Fase improve adalah tahap perbaikan bertujuan untuk menghasilkan gagasan, desain, dan implementasi perbaikan dan memvalidasi perbaikannya. Pada fase ini metode yang digunakan adalah metode Taguchi. Metode Taguchi adalah metode yang berfokus pada peningkatan desain proses manufaktur dan produk (Bagchi, 1993). Metode ini bertujuan untuk memperbaiki kualitas produk dan proses dengan menekankan pentingnya perencanaan pada produk yang kokoh (robust) sehingga rancangan produk dan proses dapat berfungsi dengan baik.

\subsection{Fase Control}

Tahap ini bertujuan untuk melakukan pengendalian dan pengontrolan dari hasil-hasil peningkatan Six Sigma. Pada fase ini dilakulan pengomtrolan dapat dilakukan dengan cheeck sheet dan grafik pengendali $\mathrm{p}$.

\section{Hasil dan Pembahasan \\ 3.1 Fase Define}

Fase define yaitu mendefinisikan permasalahan yang bekaitan dengan kualitas. Berikut langkah pada fase define yaitu:

\subsubsection{Identifikasi Permasalahan}

IKM Inti Jaya memproduksi produk genteng mantili sekitar 600 - 800 buah genteng per produksi dengan angka kecacatan sekitar $70-120$ produk cacat per produksi. Dengan adanya permasalahan tersebut maka dibutuhkan perbaikan proses untuk mengurangi jumlah cacat yang dihasilkan pada proses produksi. Tujuan dari proyek Six Sigma ini adalah untuk menurunkan tingkat kecacatan produk menjadi $<20$ produk cacat per produksi.

\subsubsection{Proses Produksi dengan OPC (Operation Process Chart)}

Proses produksi pembuatan genteng mantili dapat dilihat pada gambar 1 (lampiran). Dari proses 
produksi tersebut akan diketahui proses apa saja yang dilakukan dalam membuat produk dan proses mana yang paling mempengaruhi di dalam menghasilkan kecacatan.

\subsubsection{Karakteristik Kualitas Kunci (CTQ)}

Critical to Quality (CTQ) merupakan karakteristik-karakteristik kunci yang dapat menyebabkan cacat pada genteng sehingga tidak memenuhi harapan pelanggan atau konsumen. Jenis CTQ pada produk genteng mantili ditentukan berdasarkan jenis cacat kritis. Dari hasil pengamatan dan diskusi dengan bagian produksi yang termasuk CTQ yaitu genteng pecah, genteng retak, genteng keropos dan genteng gosong.

\subsection{Fase Measure}

Fase measure adalah tahap pengukuran dengan mengumpulkan data sesuai dengan objek penelitian.

\subsubsection{Perhitungan DPMO dan Sigma Level}

Perhitungan DPMO dilakukan pada bulan 01 Januari 2018 - 20 Februari 2018 dengan total produksi sebesar 8188 unit produk dan total produk cacat sebesar 960 cacat produk. Hasil dari perhitungan DPMO sebesar 29311 dengan nilai level sigma sebesar 3,35 sigma.

\subsection{Fase Analyze}

Fase analyze digunakan untuk mengetahui pokok permasalahan dengan target adanya peluang perbaikan dengan mengidentifikasi akar penyebab atau sumber kegagalan produk.

\subsubsection{Identifikasi Akar Penyebab Masalah}

Penggunaan diagram fishbone berdasarkan karakteristik kualitas kunci (CTQ) yang didapatkan dari hasil pengamatan dan brainstorming dengan pihak perusahaan. Hasil analisis dari diagram fishone yaitu terdapat dua faktor. Faktor yang tidak dapat dikendalikan meliputi faktor manusia dan lingkungan. Sedangkan faktor yang dapat dikendalikan meliputi faktor material, metode dan mesin. Dari hasil Fishbone didapatkan faktor penyebab terbesar adalah material. Material yang akan menjadi faktor kontrol antara lain semen, pasir, air dan wadek.

\subsection{Fase improve}

Pada fase ini yaitu melakukan perbaikan terhadap permasalahan yaitu penurunan tingkat kecacatan produk dengan mengoptimalisasikan proses untuk mewujudkan produk yang kokoh. Proses perbaikan dengan metode Taguchi yang digunakan untuk memperoleh setting level yang optimal.

\subsubsection{Tahap Perencanaan Eksperimen}

\subsubsection{Perumusan Masalah}

Adanya produk cacat pada genteng mantili sehingga diperlukan cara untuk mengetahui faktor terkontrol yang mempengaruhi kualitas produk dan bagaimana kombinasi setting level optimal sehingga dapat meminimasi tingkat kecacatan produk.

\subsubsection{Tujuan Eksperimen}

Mengidentifikasi faktor terkontrol yang mempengaruhi kualitas produk genteng dan menemukan kombinasi setting level yang optimal.

\subsubsection{Identifikasi Faktor-Faktor (Variabel Bebas)}

Melakukan identifikasi dengan memilih faktorfaktor mana saja yang dianggap berpengaruh. Pada penelitian ini, faktor-faktor yang mempengaruhi tingkat kecacatan pada produk genteng mantili terdapat pada diagram fishbone

\subsubsection{Pemilihan Faktor Kontrol dan Faktor Gangguan (noise)}

Pemilihan faktor kontrol dan faktor noise yang dilihat dari faktor-faktor pada variabel bebas. Untuk faktor noise yaitu faktor manusia dan lingkungan. Sedangkan faktor kontrol yaitu faktor material, metode dan mesin. Pada penelitian ini faktor kontrol yang digunakan adalah faktor material dengan pertimbangan bahwa faktor ini lebih mudah untuk diperbaiki dibandingkan dengan faktor yang lainnya karena terdapat beberapa kendala dalam memperbaikinnya. Faktor kontrol pada faktor material meliputi rasio tanah liat, wadek, air dan pasir

\subsubsection{Penetapan Jumlah Level}

Penentuan level ditentukan dari data perusahaan dan hasil diskusi dengan para pekerja dan pemilik usaha di mana bahan baku tersebut digunakan untuk membuat 3 unit produk genteng. Hasil data dapat dilihat pada Tabel 1 .

\subsubsection{Perhitungan Degree Of Freedom}

Degree of freedom didapatkan dari faktor-faktor yang digunakan dalam eksperimen. Hasil dari perhitungan yaitu 8 degree of freedom faktor.

\subsubsection{Penetapan Matriks Orthogonal}

Untuk memilih matriks orthogonal yang cocok adalah dengan hasil dari degree of freedom harus lebih dari atau sama dengan degree of freedom pada faktor. Matriks orthogonal yang akan digunakan adalah $\mathrm{L}_{9}\left(3^{4}\right)$

\subsubsection{Tahap Pelaksanaan Eksperimen}

\subsubsection{Perhitungan Analysis of Variance (ANOVA)}

Perhitungan analysis of variance (ANOVA) pada data atribut yang bertujuan untuk mengetahui faktor-faktor yang mempengaruhi suatu nilai respons. Hasil dari perhitungan analysis of variance (ANOVA) dapat dilihat pada tabel 2.

Dari tabel 2 dapat dilihat bahwa hasil dari semua Fhit (Fratio) $>$ Ftabel $(0,05 ; 2 ; 216)$ (penggunaan Ftabel dengan toleransi $5 \%$ yaitu besar toleransi) sehingga $\mathrm{H}_{0}$ ditolak, artinya ada pengaruh faktor terhadap tingkat kecacatan produk genteng mantili. 
Tabel 1. Level Faktor yang Berpengaruh

\begin{tabular}{cccc}
\hline \multirow{2}{*}{ Faktor Berpengaruh } & \multicolumn{3}{c}{ Level Faktor } \\
\cline { 2 - 4 } & 1 & 2 & 3 \\
\hline Rasio tanah liat (kg) & $80 \%=3$ & $70 \%=2,8$ & $70 \%=2,8$ \\
Pasir (kg) & $15 \%=0,6$ & $15 \%=0,6$ & $15 \%=0,75$ \\
Wadek (kg) & $5 \%=0,2$ & $15 \%=0,65$ & 0 \\
Air (liter) & 0,5 & 0,5 & 0,7 \\
\hline
\end{tabular}

Tabel 2. Hasil Analysis of Variance (ANOVA)

\begin{tabular}{cccccc}
\hline Sumber & Sq & Df & Mq & F-ratio & Sq” \\
\hline A & 23,676 & 2 & 11,838 & 18,932 & 22,425 \\
B & 21,973 & 2 & 10,986 & 17,570 & 20,722 \\
C & 23,676 & 2 & 11,838 & 18,932 & 22,425 \\
D & 20,610 & 2 & 10,305 & 16,480 & 19,359 \\
E & 135,064 & 216 & 0,62 & 1 & 140,066 \\
ST & 225 & 224 & & & 225 \\
\hline
\end{tabular}

Tabel 3. Hasil ANOVA Setelah Polling Up

\begin{tabular}{ccccccc}
\hline Sumber & Pool & Sq & Df & Mq & F-ratio & Sq" \\
\hline A & & 23,676 & 2 & 11,838 & 14,660 & 22,061 \\
B & Y & 21,973 & 2 & 10,986 & & \\
C & & 23,676 & 2 & 11,838 & 14,660 & 22,061 \\
D & Y & 20,610 & 2 & 10,305 & & \\
E & Y & 135,064 & 216 & 0,62 & 1 & \\
Polled e & & 177,647 & 220 & 0,807 & & 0 \\
ST & & 225 & 224 & & & 225 \\
\hline
\end{tabular}

Tabel 4. Hasil Perhitungan Persen Kontribusi

\begin{tabular}{ccccccc}
\hline Sumber & $\mathrm{Sq}$ & $\mathrm{Df}$ & $\mathrm{Mq}$ & F-ratio & $\mathrm{Sq} "$ & $\rho \%$ \\
\hline $\mathrm{A}$ & 23,676 & 2 & 11,838 & 18,932 & 22,425 & 9,97 \\
\hline $\mathrm{B}$ & 21,973 & 2 & 10,986 & 17,570 & 20,722 & 9,21 \\
\hline $\mathrm{C}$ & 23,676 & 2 & 11,838 & 18,932 & 22,425 & 9,97 \\
\hline $\mathrm{D}$ & 20,610 & 2 & 10,305 & 16,480 & 19,359 & 8,60 \\
\hline $\mathrm{E}$ & 135,064 & 216 & 0,62 & 1 & 140,066 & 62,25 \\
\hline ST & 225 & 224 & & & 225 & 100 \\
\hline
\end{tabular}

\subsubsection{Polling $U p$}

Pengantisipasian adanya kesalahan disarankan untuk menggunakan separuh dari jumlah derajat kebebasan pada matriks orthogonal. Polling up dilakukan pada faktor terkecil yaitu pada faktor B dan faktor D yang dilihat dari nilai variansi terkecil (Mq). Hasil perhitungan polling up dapat dilihat pada Tabel 3.

Dari Tabel 3 dapat dilihat bahwa faktor-faktor yang memiliki pengaruh dalam hal meminimalkan penyimpangan terhadap hasil eksperimen secara signifikan yaitu dibuktikan dengan Fratio $>$ Ftabel sehingga dapat dikatakan bahwa faktor A dan faktor C memiliki kontribusi dalam menurunkan tingkat kecacatan dengan nilai tertinggi jika dibandingkan dengan faktor B dan faktor D.

\subsubsection{Penentuan Setting Level Optimal}

Digunakan untuk meningkatkan kualitas dengan mengurangi kecacatan dan juga mengatur target yang diinginakan dan sesuai dengan spesifikasi. Hasil dari kombinasi level optimal yang didapatkan yaitu faktor A level 3 yaitu rasio tanah liat sebesar $80 \%=3 \mathrm{~kg}$; faktor B level 2 yaitu pasir sebesar $15 \%=0,65 \mathrm{~kg}$; faktor C level 2 yaitu wadek sebesar $15 \%=0,65 \mathrm{~kg}$; faktor D level 2 yaitu air sebesar 0,6 lt.

\subsubsection{Nilai Rasio S/N (SNR)}

Bertujuan untuk mengetahui nilai yang mempengaruhi variansi pada eksperimen. Pada penelitian ini faktor yang diamati adalah persentase cacat sehingga menggunakan SNR-fraction defective yaitu omega transformation $(\Omega)$. Untuk persentase cacat $\rho$ adalah $0 \%$ di mana semakin kecil nilai $\rho$ maka akan semakin baik. Dari hasil perhitungan didapatkan hasil nilai $\rho$ sebesar $0,26 \%$. Nilai tersebut mendekati $0 \%$ sehingga semakin kecil prosentase cacat maka semakin baik.

\subsubsection{Interpretasi Hasil Eksperimen \\ 3.4.3.1 Persen Kontribusi}

Yaitu porsi masing-masing faktor dan atau interaksi faktor yang signifikan terhadap total varians yang diamati. Hasil perhitungannya dapat dilihat pada Tabel 4. 
Tabel 5. Hasil Eksperimen Konfirmasi

\begin{tabular}{ccccccccc}
\hline Eks & $\begin{array}{c}\text { Jumlah } \\
\text { produk }\end{array}$ & Cacat & & Jenis cacat & $\begin{array}{c}\text { Persentase } \\
\text { cacat }\end{array}$ & SNR \\
\hline 1 & 65 & 2 & 1 & 0 & 0 & 1 & 3,1 & $-14,98$ \\
\hline 2 & 65 & 2 & 0 & 1 & 1 & 0 & 3,1 & $-14,98$ \\
\hline 3 & 65 & 3 & 1 & 1 & 1 & 0 & 4,6 & $-13,15$ \\
\hline 4 & 65 & 2 & 1 & 1 & 0 & 0 & 3,1 & $-14,98$ \\
\hline 5 & 65 & 2 & 0 & 1 & 0 & 1 & 3,1 & $-14,98$ \\
\hline 6 & 65 & 3 & 1 & 0 & 1 & 1 & 4,6 & $-13,15$ \\
\hline Jumlah & 390 & 14 & 4 & 4 & 3 & 3 & 21,54 & \\
\hline Rata - rata & 65 & 2,33 & & & & & 4,59 & \\
\hline
\end{tabular}

Dari tabel 4 dapat dilihat bahwa persen kontribusi error (e) $\geq 50 \%$ yaitu $62,25 \% \geq 50 \%$ artinya ada faktor yang berpengaruh dan terdapat error yang terlalu besar (Soejanto, 2009).

\subsubsection{Perkiraan Kondisi Optimal dan Selang Kepercayaan}

Memperkirakan kondisi optimal yang bertujuan untuk menurunkan tingkat kecacatan yang dianggap sebagai selang kepercayaan. Dengan hasil selang kepercayaan untuk proses optimal yaitu $0,17694 \leq \mu_{\text {prediksi }}$ $\leq 0,410526$.

\subsubsection{Eksperimen Konfirmasi}

Eksperimen konfirmasi dilakukan untuk memvalidasi hasil dari setting faktor dan level dari hasil setting level yang telah didapatkan. Untuk eksperimen konfirmasi dilakukan 6 kali eksperimen dengan 1 kali eksperimen memproduksi sebanyak 65 genteng mantili. Penentuan sampel sebanyak 65 didapatkan dari hasil pertimbangan efisiensi dari produk untuk dikonfirmasi. Hasil eksperimen konfirmasi dapat dilihat pada tabel 5 .

\subsubsection{Selang Kepercayaan Eksperimen Konfirmasi}

Membandingkan selang kepercayaan dengan eksperimen konfirmasi dengan setting optimal yang diperoleh dapat dijadikan acuan atau tidak, dengan ketentuan eksperimen konfirmasi masih terletak di antara selang kepercayaan. Dengan hasil, selang kepercayaan masih berada dibatas optimal $\left(0,033623 \leq \mu_{\text {konfirmasi }} \leq\right.$ 0,038172 berada di dalam rentang $0,17694 \leq \mu_{\text {prediksi }} \leq$ 0,410526 ) sehingga dapat disimpulkan bahwa keputusan diterima dalam artian hasil dari eksperimen Taguchi dapat diproduksi dan setting level optimal dapat dijadikan acuan dalam proses pembuatan produk genteng mantili di IKM Inti Jaya.

\subsubsection{Tahap Implementasi Six Sigma}

Setelah dilakukan dilakukan eksperimen diketahui bahwa kombinasi level yang optimal dapat dijadikan acuan kemudian dilakukan implementasi sebagai usulan perbaikan untuk melihat apakah memberikan hasil lebih baik atau tidak. Setelah dilakukan perbaikan terdapat penurunan nilai DPMO menjadi 8974,35. Sedangkan terjadi kenaikan pada nilai level sigma menjadi 3,99 sigma

\subsection{Fase Control}

Fase ini digunakan untuk melakukan pengendalian dari hasil-hasil peningkatan Six Sigma. Untuk melakukan tahap kontrol pada proses pembuatan genteng yaitu menggunakan check sheet untuk memastikan bahwa kombinasi level faktor yang digunakan sesuai dengan kombinasi level faktor yang optimal setelah dilakukan penelitian. Selain check sheet, alat pengendali kualitas yang digunakan adalah grafik pengendali $p$. Grafik pengendali $p$ ini digunakan untuk melihat apakah masih ada data yang tidak sesuai (out of control) sehingga grafik tersebut dapat dijadikan acuan untuk proses produksi selanjutnya atau tidak.

\section{Kesimpulan}

Metode Six Sigma yang diaplikasikan pada IKM Inti Jaya telah mendapatkan hasil penuruan nilai DPMO dari 29311 menjadi 8974,35 dan mengalami kenaikan nilai sigma level dari 3,35 menjadi 3,99 sigma. Hal ini mendukung beberapa penelitian terdahulu yang telah mengaplikasikan metode Six Sigma dalam beberapa obyek produk yang berbeda. Rekomendasi perbaikan proses produksi untuk komposisi material yaitu rasio tanah liat sebesar $80 \%=3 \mathrm{~kg}$; pasir sebesar $15 \%=0,65$ $\mathrm{kg}$; wadek sebesar $15 \%=0,65 \mathrm{~kg}$; dan air sebesar 0,6 lt.

\section{Daftar Pustaka}

Ariani, D. W. (2014). Manajemen kualita.

Bagchi, T. P. (1993). Taguchi methods explained:Practical step to robust design. Prentice-Hall.

Caesaron, D., \& Simatupang, S. Y. (2015). Implementasi pendekatan DMAIC untuk perbaikan proses produksi pipa PVC (studi kasus PT. Rusli Vinilon). Jurnal Metris, 91-96.

Dewi, S. K. (2012). Minimasi Defect Produk Dengan Konsep Six Sigma. Jurnal Teknik Industri, 8.

Fithri, P. (2019). SIX SIGMA SEBAGAI ALAT PENGENDALIAN MUTU PADA HASIL PRODUKSI KAIN MENTAH PT UNITEX, TBK.J@TI Undip, 10. 
Fransiscus, H., Juwono, P. C., \& Astari, I. S. (2014). Implementasi metode Six Sigma DMAIC untuk mengurangi paint bucket cacat di PT X. Jurnal Rekayasa Sistem Industri, 53-64.

Ghiffari, I., Harsono, A., \& Bakar, A. (2013). Analisis Six Sigma untuk Mengurangi Jumlah Cacat di Stasiun Kerja Sablon (Studi Kasus: CV. Miracle). Reka Integra, 1.

Gijo, E., \& Scaria, J. (2010). Reducing rejection and rework by application of Six Sigma methodology in manufacturing process. International Journal of Six Sigma and Competitive Advantage, 77-90.

Handayani, N. U., P, S. N., \& Wibowo, H. A. (2012). UPAYA PENINGKATAN KUALITAS PADA PEMBUATAN RODA CASTOR 5" MENGGUNAKAN METODE SIX SIGMA DAN PENGENDALIAN PROSES STATISTIK (Studi Kasus Di Unit Komponen Plastik PT. Mega Andalan Kalasan).J@ti undip, 9.

Juran, J., \& Godfrey, A. B. (1999). Quality handbook. McGraw-Hill.

Shanmugaraja, M., Nataraj, M., \& Gunasekaran, N. (2011). Quality and productivity improvement using Six Sigma and Taguchi methods. International Journal of Business Excellence, 544-572.

Soejanto, I. (2009). Desain Eksperimen dengan Metode Taguchi. Yogyakarta: Graha Ilmu.

Supriyadi, S., Ramayanti, G., \& Roberto, A. C. (2017). Analisis Kualitas Produk dengan Pendekatan Six Sigma. Seminar Nasional Riset Terapan, (pp. 7-13).

Wibisono, Y. Y., \& Suteja, T. (2013). Implementasi Metode DMAIC-Six Sigma dalam Perbaikan Mutu di Industri Kecil Menengah: Studi Kasus Perbaikan Mutu Produk Spring Adjuster di PT. $\mathrm{X}$. 